Maurer School of Law: Indiana University

Digital Repository @ Maurer Law

1972

\title{
The National Labor Relations Board Voting Study: A Preliminary Report
}

Julius G. Getman

Indiana University School of Law

Stephen B. Goldberg

University of Illinois School of Law

Jeanne B. Herman

University of Illinois at Urbana-Champaign

Follow this and additional works at: https://www.repository.law.indiana.edu/facpub

Part of the Labor and Employment Law Commons

\section{Recommended Citation}

Getman, Julius G.; Goldberg, Stephen B.; and Herman, Jeanne B., "The National Labor Relations Board Voting Study: A Preliminary Report" (1972). Articles by Maurer Faculty. 1910.

https://www.repository.law.indiana.edu/facpub/1910

This Article is brought to you for free and open access by the Faculty Scholarship at Digital Repository @ Maurer Law. It has been accepted for inclusion in Articles by Maurer Faculty by an authorized administrator of Digital Repository @ Maurer Law. For more information, please contact rvaughan@indiana.edu. 


\section{THE NATIONAL LABOR RELATIONS BOARD VOTING STUDY: A PRELIMINARY REPORT}

JULIUS G. GETMAN,* STEPHEN B. GOLDBERG,** and JEANNE B. HERMAN***

\section{INTRODUCTION}

$\mathrm{T}$ HE National Labor Relations Act provides that if a majority of employees choose union representation, the union shall serve as the exclusive bargaining agent for all employees in the unit. ${ }^{1}$ The decision concerning union representation is typically made in an election preceded by a campaign in which the union tries to induce the employees to vote for representation and the employer tries to induce them to vote against it. The Labor Board, which conducts the election, has devised elaborate and complicated rules governing campaign behavior, particularly of employers.

Because of the number, complexity, and significance of the Board's rules, it is common for the losing party to file objections to the election. In fiscal 1970, objections were filed in 1207 of 8437 elections conducted. ${ }^{2}$ Each objection, whether or not meritorious, involves considerable investigation, frequently a hearing, a written report, sometimes an appeal to the Board and sometimes a court case challenging the Board's decision. The cost of administering such a system-the expenditure of time, money and personnel by the government, by the union, and by the employer-is substantial. Moreover, although the normal remedy for a violation of the Board's campaign rules is an election rerun, if the Board deems the violation sufficiently serious it can order the employer to recognize and bargain with the union even though the union lost the election. ${ }^{3}$ Thus the Board's rules concerning the assumed impact of certain types of campaign tactics are of great significance to employers and unions.

* Visiting Professor of Law, University of Chicago; Professor of Law, Indiana University.

** Professor of Law, University of minois.

*** Assistant Professor of Psychology, University of Illinois. The research described in this paper has been financed by a grant from the National Science Foundation.

129 U.S.C. 158(a)(5), 159(a) (1970).

235 NLRB Ann. Rep. 174-75 (1970).

${ }^{8}$ NLRB v. Gissel Packing Co., 395 U.S. 575 (1969). 
Yet the Board has formulated its rules on the basis of untested assumptions concerning the likely impact of employer and union conduct on employee free choice. ${ }^{4}$ The Board assumes that employees are highly attentive to, and susceptible to being influenced by, the campaigns of both the employer and the union, and, in particular, that employees are aware of and susceptible to threats of retaliation if they vote for the union and to promises of benefit if they do not. For the past three years we have been engaged in a field study to test the validity of these and other assumptions. ${ }^{\circ}$ We are currently in the data-collection stage, which was preceded by test studies of six Board-conducted elections. This article reports on our test studies and discusses the significance of our data and the research decisions that we have made.

\section{Research Design}

We use the panel technique, which has proved successful in studying voting behavior in political elections. The technique involves interviewing the same voters at different stages of an election campaign. The researcher is able not only to ascertain whether the proportion of voters intending to vote for each party changed but also to identify and study those who changed their votes. We conduct two interviews with a randomly selected sample of employees. The first-wave interview is scheduled after the union card-signing drive ${ }^{7}$ but

4 See Getman v. NLRB, 450 F.2d 670, 675-76 (D.C. Cir. 1971), stay denied, 404 U.S. 1204 (1971); Derek C. Bok, The Regulation of Campaign Tactics in Representation Elections Under the National Labor Relations Act, 78 Harv. L. Rev. 38, 46-53, 88-90 (1964) ; Bernard Samoff, NLRB Elections: Uncertainty and Certainty, 117 U. Pa. L. Rev. 228 (1968); Merton C. Bernstein, The NLRB's Adjudication-Rule Making Dilemma Under the Administrative Procedure Act, 79 Yale L.J. 571, 582 (1970); Note, Behavioral and Non-Behavioral Approaches to NLRB Representation Cases, 45 Ind. L.J. 276 (1970).

6 Previous field studies dealing with the impact of the preelection campaign are discussed in: Irving Brotslaw, Attitude of Retail Workers Toward Union Organization, 18 Labor L. J. 149 (1967); A Survey of Voters in National Labor Relations Board Elections (unpublished report prepared by. Political Science Department Research Analysts, San Fernando Valley State College, for the Los Angeles, Orange Counties Organizing Comm, AFL-CIO, 1968); Note, Examination of Two Aspects of the NLRB's Representation Election: Employee Attitudes and Board Inferences, 3 Akrón L. Rev. 218 (1970). An unsuccessful study is discussed in Donald F. Roy, The Role of the Researcher in the Study of Social Conflict: A Theory of Protective Distortion of Response, 24 Human Organization 262 (1965). Archival studies include: J.E. Drotning, The Union Representation Election: A Study in Persuasion, 88 Monthly Lab. Rev. 938 (1965); Daniel H. Pollitt, NLRB Re-Run Elections: A Study, 41 N.C.L. Rev. 209 (1963); J. L. Blackman, Relative Severity of Employer Unfair Labor Practices, 22 Labor L. J. 67 (1971). These latter two studies are discussed in Julius G. Getman \& Stephen B. Goldberg, Bargaining Orders and the Myth of NLRB Expertise, 39 U. Chi. L. Rev.-(1972) (forthcoming).

- See, e.g., Bernard R. Berelson, Paul F. Lazarsfeld \& William N. McPhee, Voting: A Study of Opinion Formation in a Presidential Campaign (1954); Paul F. Lazarsfeld, Bernard Berelson \& Hazel Gaudet, The People's Choice (3d ed. 1969); Angus Campbel et al., The American Voter (1960).

7 In order to get an election order a union must obtain cards designating the union 
before the company campaign has begun in earnest. We collect attitude and demographic data about the respondents and determine their voting intentions. The second-wave interview, which is conducted immediately after the election, collects information both on voting and on perception of the issues raised in the company and union campaigns.

\section{Relationships Between Vote and Demographic and Job Cenaracteristics, Attitudes and the Camopaign}

\section{A. Introduction}

The Board assumes that voting is significantly influenced by the campaign, especially by employer threats and promises. If, however, voting behavior can be predicted from data collected prior to the campaign, the specific content of the campaign would appear largely irrelevant in shaping voting behavior. Accordingly, we have attempted to predict votes on the basis of information collected at the first interview.

\section{B. Relationship Between Vote and Demographic and Job Characteristics}

Demographic information collected at the first wave interview includes the respondent's age, sex, marital status, race, education, and prior union membership of both himself and his family. Job-characteristic variables explored include length of employment, hours, and pay rate. None of the job characteristics was found to be related to voting behavior, and, of the demographic characteristics, only sex was related significantly to vote and then only in election $B, 8$ where the women were more inclined to vote for the union than the men. While there do not appear to be really important relationships between demographic or job characteristics and vote in either of the elections, the variance of these variables was restricted. Low level but general relationships may emerge across elections.

\section{Relationship Between Attitudes and Vote}

We measure attitudes about unions by asking each employee to agree or disagree with the following statements:

as bargaining representative signed by at least $30 \%$ of the employees. Often a union will attempt to get more, either to insure victory or to set up the possibility of a bargaining order pursuant to NLRB v. Gissel Packing Co., 395 U.S. 595 (1969).

8 The second of the two elections on which the findings reported in this article were based.

9 The correlation between sex and vote was .31 , significant beyond the .05 level (i.e., the probability that this correlation was due solely. to random factors was less than 5 per cent). 
a) Organized labor is becoming too strong.

b) Unions ensure fair treatment of employees on matters such as promotion, pay, and seniority rights.

c) Unions help the working man to get better wages and hours.

d) Unions interfere with good relations between employees and employers.

e) Unions have been responsible for many of the laws that benefit working people.

f) Many union leaders are corrupt.

g) Unions provide the employee with a voice in determining wages, hours, and working conditions so that these decisions are not made by the employer alone.

h) Union dues and initiation fees are too high.

i) Unions hardly ever call unnecessary strikes.

j) Unions are a major cause of inflation.

We form a Union Attitude Index (UAI) for each respondent by summing his responses to the ten items.10 We also ask employees to evaluate their work situation by indicating whether they are satisfied or dissatisfied with each of the following aspects of their job:

a) Wages.

b) Hours.

c) Type of work.

d) Job security.

e) Fringe benefits, for example, vacations, holiday pay, insurance, sick leave.

f) The treatment of employees by company management.

g) The company's recognition of good work.

h) The company's efficiency.

The Job Satisfaction Index (JSI) represents the sum of the responses to these eight items. ${ }^{11}$

Intent to vote for or against the union is measured both directly and indirectly at the first interview. Direct measures include questions asking whether or not the employee has signed a union authorization card and what his voting intention is at this stage of the campaign. Each employee is also asked, "If the election were held tomorrow, would you vote for or against the Union." Responses are coded "for the Union," "against the Union" or "uncertain." Questions asked on the first interview that measure vote intent less directly include:

4. If for some reason you were to decide to quit your job with this Company,

10 The reliability of the UAI, estimated using $\mathrm{KR} 21$ as a measure of internal consistency (G. F. Kuder \& M. W. Richardson, The Theory of Estimation of Test Reliability, 2 Psychometrika $150-160$ (1937)), was .61 in election A and .70 in election B. These figures indicate that the respondents are answering our union attitude questions in a generally consistent fashion.

11 The reliability estimates ( $K R$ 21) for the JSI were .68 for election A and .80 for election $\mathbf{B}$. 
do you think it would be easy or difficult for you to find as good a job elsewhere?

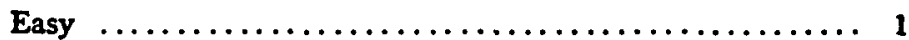

Difficult $\ldots \ldots \ldots \ldots \ldots \ldots \ldots \ldots \ldots \ldots \ldots \ldots \ldots, 2$

(Don't know) $\ldots \ldots \ldots \ldots \ldots \ldots \ldots \ldots \ldots \ldots \ldots, 8$

22a. Hove you participated in any way in the election campaign?

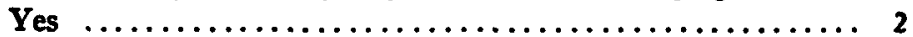

No $\ldots \ldots \ldots \ldots \ldots \ldots \ldots \ldots \ldots \ldots \ldots \ldots \ldots \ldots \ldots, l$

25. Regardless of the way you intend to vote, do you think a majority of the voters will or will not choose Union representation?

Will choose Union $\ldots \ldots \ldots \ldots \ldots \ldots \ldots \ldots \ldots \ldots \ldots, 3$

Will not choose Union $\ldots \ldots \ldots \ldots \ldots \ldots \ldots \ldots \ldots \ldots, 1$

(Don't know) ............................. 2

27. Do you think it would be a good thing or a bad thing if the Union were voted in?

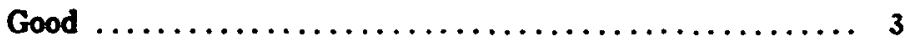

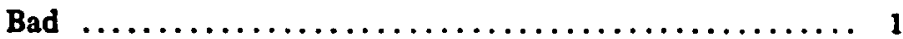

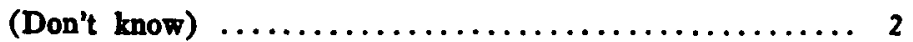

30. How much have you talked to your friends at work about the election?

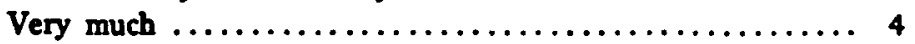

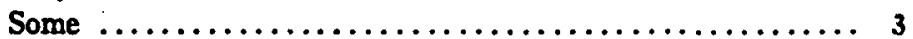

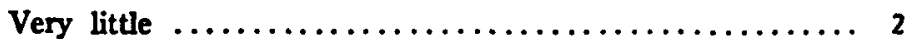

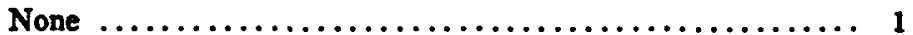

31. How many, if any, of your friends at work do you think will vote for the Union-most, some, only a few, or none of them?

Most .................................... 4

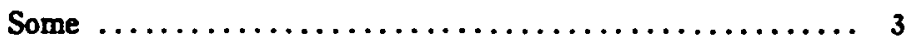

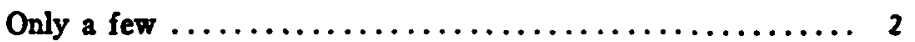

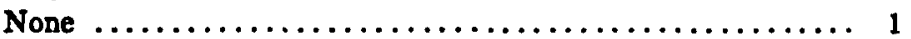

(Don't know) $\ldots \ldots \ldots \ldots \ldots \ldots \ldots \ldots \ldots \ldots \ldots, 8$

Tables 1 and 2 present the significant correlations between the attitudinal data collected at the initial interview and the votes in elections $\mathbf{A}$ and $\mathbf{B}$. The tables show a high degree of correspondence across these two elections despite very different unit characteristics. ${ }^{12}$ In both elections a positive attitude towards unions in general was highly related to a vote for the union $(\mathrm{Ar}=.47 ; \mathrm{Br}=.58)$; high job satisfaction was related to a vote against the union ( $\mathrm{Ar}=.58 ; \mathrm{Br}=-.58$ ). The significant correlations between card sign and vote $(\mathrm{Ar}=.75 ; \mathrm{Br}=.53$ ) and vote intent and vote ( $\mathrm{Ar}=$ $.56 ; \mathrm{B} \mathrm{r}=.73$ ) show that signing a union card or indicating an intent to

12 Election A, which took place in a medium-sized midwestern city, was conducted in two stores of a large discount department-store chain. The Retail Clerks lost this election, 112 to 50 . Election $B$ involved employees of a manufacturing company in Chicago. The Steelworkers lost this election, 183-93. 
TABLE 1

Correlations Between Initial INTERview Data and Vote-Election A

\begin{tabular}{lrrrrrrrrr}
\hline \hline & 1 & 2 & 3 & 4 & 5 & 6 & 7 & 8 & 9 \\
\hline 1. Participation & & & & & & & & & \\
in election & 1.00 & & & & & & & \\
$\begin{array}{l}\text { campaign } \\
\text { 2. Opinion as to } \\
\text { desirability of }\end{array}$ & & & & & & & & \\
$\begin{array}{l}\text { Union victory } \\
\text { Vote intent }\end{array}$ & .39 & 1.00 & & & & & & \\
3. Vo & .63 & 1.00 & & & & & \\
4. Amount of & & & & & & & & \\
$\quad$ discussion & & & & & & & & \\
$\quad$ about election & .48 & .21 & .17 & 1.00 & & & & \\
5. Prediction of & & & & & & & & \\
friends' vote & .32 & .58 & .50 & .24 & 1.00 & & & \\
6. Card sign & .55 & .59 & .48 & .32 & .51 & 1.00 & & \\
7. UAI & .43 & .48 & .52 & .43 & .20 & .57 & 1.00 & & \\
8. JSI & -.40 & -.54 & -.44 & -.34 & -.54 & -.65 & -.33 & 1.00 \\
9. Vote & .66 & .59 & .46 & .51 & .47 & .75 & .47 & -.58 & 1.00 \\
\hline
\end{tabular}

Note: $x=.29 ; p \leq .05 ; N=46.13$

vote for or against the union prior to the election campaign is highly predictive of vote. Other evidence that an employee is likely to vote for the union is that he participated in the early stages of the union campaign, discussed the election with his friends, believes that a union victory would be desirable and believes that his friends or a majority of the unit will vote for the union.

The results presented in Tables 1 and 2 identify a clear trend: an employee's voting behavior is consistent with his attitudes, voting intent and precampaign behavior. This trend is present in both elections and is typical of all six pretest elections that we have completed.

The exploratory analyses described above demonstrate that stable relationships do exist between vote and precampaign attitudes, behavior and intent. Multiple regression was used in the second stage of analysis in an attempt to predict an employee's vote from his precampaign attitudes towards the job and unions in general. ${ }^{14}$ Table 3 indicates the accuracy of the cross-

18 The correlation coefficients in Tables 1 and 2 may be interpreted as follows: Vote was scored so that a high score represented a vote for the union, a low score a vote against the union. High positive correlations between data collected in the preliminary interview and vote indicate that individuals who give a high score response to an item tend to be union voters. High negative correlations indicate that individuals who give a high score response on the item tend to vote against the union. For example, employees who are highly satisfied with their jobs tend to vote against the union, reflected by the high negative correlation between JSI and vote.

14 Multiple regression is a procedure for determining the relationship between a criterion, vote, and combination of predictors. Maurice M. Tatsuoka, Validation Studies, 


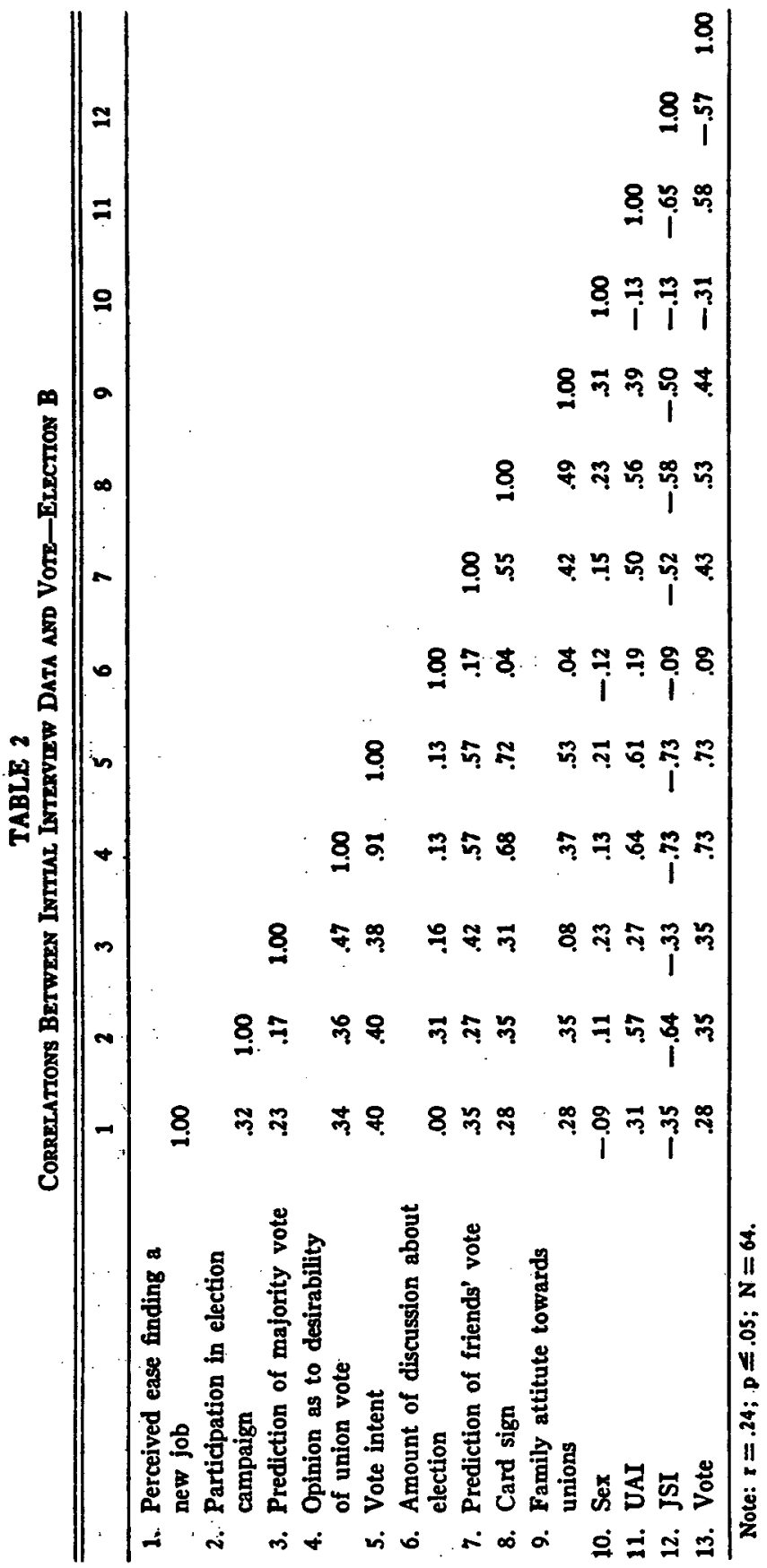


TABLE 3

Cross Valmated Vote Predictions

\begin{tabular}{llccc}
\hline \hline & & Election $\mathrm{A}$ & & \\
& & & Predicted Vote & \\
\cline { 3 - 5 } & & For Union & Against Union & Totals \\
\hline Actual & For Union & 16 & 2 & 18 \\
Vote & Against Union & $\frac{7}{23}$ & $\frac{21}{23}$ & $\frac{28}{46}$
\end{tabular}

Election B

\begin{tabular}{llccc} 
& & \multicolumn{3}{c}{ Predicted Vote } \\
\cline { 3 - 5 } & & For Union & Against Union & Totals \\
\hline Actual & For Union & 20 & 7 & 27 \\
Vote & Against Union & $\frac{4}{24}$ & $\frac{33}{40}$ & $\frac{37}{64}$ \\
\hline
\end{tabular}

TABLE 4

Predictions of Swrtchens

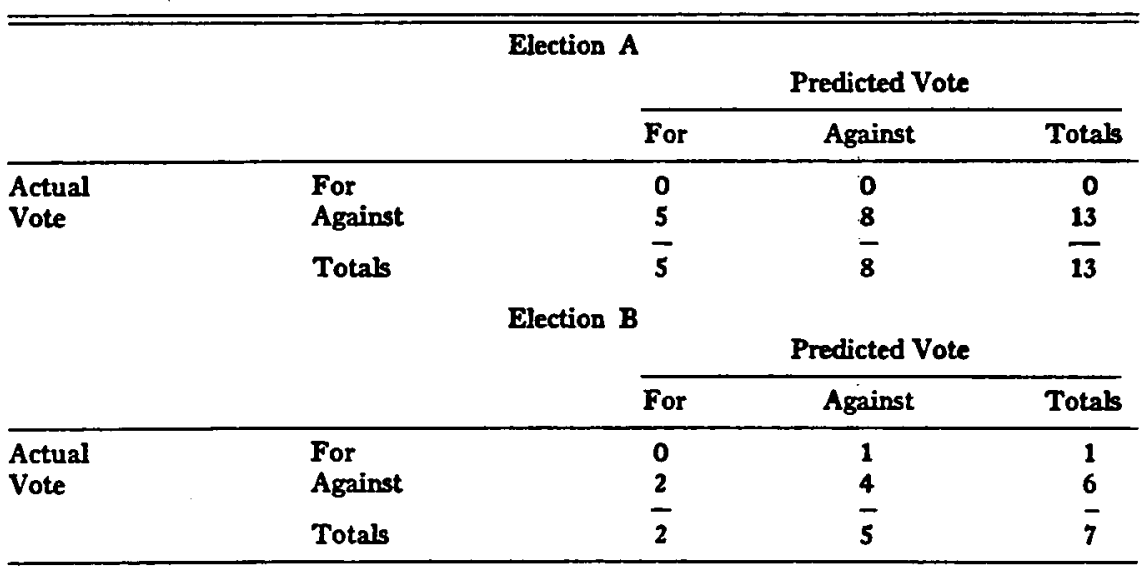

(Inst. for Personality \& Ability Testing, Champaign, Ill., Selected Topics in Advanced Statistics, No. 5, 1969). The multiple correlation predicting vote from union and company attitudes in election A was .65 and in election B, .63. Since multiple linear regression maximizes the prediction within each election, the cross-validated multiple correlations .62 in election $\mathrm{A}$ and .59 in election $\mathrm{B}$ give a more accurate estimate of the strength of the relationship between prior attitudes and vote. The individual predictions (Tables 3 and 4) were determined by a cross-validated classification technique. William W. Cooley \& Paul R. Lohnes, Multivariate Procedures for the Behavioral Sciences (1962). UAI and JSI mean scores of the groups voting for and against the union in one election are compared to mean scores in another election. An employee is predicted to vote in the same way as the group that his scores most resemble. 
validated predictions. In election $A$ the votes of 37 of 46 employees were predicted correctly, and in election B 53 of 64 , on the basis of precampaign union and company attitude data only. Table 4 indicates that in many cases an employee's actual vote is predictable from his precampaign attitudes even though be voted differently from his original intention. In election $\mathbf{A}$ the votes of 8 of 13 switchers were correctly predicted; in election B 4 of 6.15

We were thus able to predict the votes of more than 80 per cent of the electorate, including switchers, solely on the basis of voting intentions and precampaign attitudes towards unions in general and the company. This suggests that for the great bulk of the employees the campaign may not be significant in altering an initial predisposition to vote for or against union representation. That is not to say that the campaign does not strengthen that predisposition; but it does not appear to change it. The votes of the approximately 20 per cent whose prior attitudes were not predictive of their voting behavior are more likely to have been influenced by the campaign. Accordingly, in analyzing the extent to which employees appear to have been influenced by the campaign we shall focus on those respondents.

\section{Relationship Between Campaign Familiarity and Vote}

The Board assumes that employees generally are attentive to the campaign and that vote switching is a product of the campaign. One way of testing the Board's hypotheses is by measuring campaign familiarity and comparing the familiarity of union voters, company voters and switchers. Another is by correlating perception of individual campaign issues and vote.

To determine employees' familiarity with the campaigns of the parties, we proceed in the following fashion. After the election we interview company and union officials involved in the campaign, obtain copies of all their literature and speeches, and identify the major themes and arguments used by each side during the campaign. We then code the campaign using a threedigit code that contains numerical equivalents for almost any possible campaign statement or action by either side. The code contains more than 350 categories. ${ }^{16}$

16 These were employees who switched from initially supporting the union to voting against it. We failed to predict the vote of one employee in election $B$ who reported an intention to vote against union representation and an ultimate vote for the union. The rather gross inconsistencies between this employee's attitudes and ultimate vote led us to suspect that he might be lying as to vote, but in the absence of proof to this effect we have accepted his report of how be voted.

16 For example, Series 100 of the code-harmful economic consequences of unionization - contains Series 130, plant closing.

130. Plant closing will/may take place in retaliation for union victory.

131 Plant closing will/may take place because employer will not be able to afford to operate with the union because of economic impact. 
We also code each employee's responses to questions concerning the campaign and on the basis of these coded responses construct both a specific and general campaign familiarity index for each employee. An employee's specific company campaign index is the percentage of company campaign issues that he identified in detail. His general company campaign index is the percentage of company issues that he recalled generally. The union indices are similarly constructed.

The company campaign in election A emphasized the effects on the employees of possible strikes if the union won, and alleged that unionization was unnecessary, especially in such a small company, and might cause a loss of individual treatment; that union dues, initiation fees and assessments were too high; that unions were not concerned with the welfare of the employees and contributed to inflation; and that union pay rates might make it necessary for the employer to discharge employees. The company familiarity indices were based on twelve specific issues. The union campaign in election A consisted of a single, main issue-wages, and a secondary issue-union strength.

Both the company and the union campaigns in election B were much more detailed. Forty-five specific issues were identified in the company campaign, including the harmful effects of unionization on customers; the possibility of strikes, and loss of jobs and wages; the claim that unionization was unnecessary and might affect employer-employee relationships; criticisms of the union movement; and unions' alleged lack of concern about employees, inability to deliver on promises they made, etc. The union campaign in election B emphasized detailed issues of wages, pensions, sick leave, insurance, union strength, union democracy, and union success in other settings, and alleged that unions do not call unnecessary strikes.

Tables 5 and 6 present the mean percentages on the campaign familiarity indices. The same general trends appeared in both elections. Initially, the level of familiarity with the issues of the campaigns was low. Union voters were slightly more familiar with both company and union campaigns than those who voted against the union. The switchers in both campaigns-95 per cent of whom voted against the union-were less familiar with the company campaign than any other voting group. While the difference is statistically significant only in election A, clearly our findings do not support the Board's hypothesis that switching is a product of the campaign. ${ }^{17}$

In comparing the campaign familiarity of those whose votes were suc-

132 Plant closing will/may take place for reasons unknown/anspecified.

133 Plant closing has taken place at other plants after union victory.

17 The correlation between lack of familiarity with the issues of the campaign and vote switch has also been noted in the political arena. See Paul F. Lazarsfeld, Bernard Berelson \& Hazel Gaudet, supra note 6, at 69. 
TABLE 5

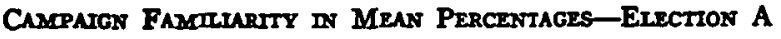

\begin{tabular}{|c|c|c|c|c|}
\hline & $\begin{array}{c}\text { Company } \\
\text { Specific }\end{array}$ & $\begin{array}{c}\text { Company } \\
\text { General }\end{array}$ & $\begin{array}{l}\text { Union } \\
\text { General }\end{array}$ & $\dot{\mathbf{N}}$ \\
\hline Total Unit & 12.30 & 18.78 & 54.35 & 46 \\
\hline $\begin{array}{l}\text { For Union } \\
\text { Against Union }\end{array}$ & $\begin{array}{l}14.39 \\
10.96\end{array}$ & $\begin{array}{l}20.50 \\
17.68\end{array}$ & $\begin{array}{l}61.11 \\
50.00\end{array}$ & $\begin{array}{l}18 \\
28\end{array}$ \\
\hline $\begin{array}{l}\text { Switchers } \\
\text { Nonswitchers }\end{array}$ & $\begin{array}{r}8.69 \\
13.73\end{array}$ & $\begin{array}{l}14.54^{*} \\
20.45\end{array}$ & $\begin{array}{l}50.00 \\
56.06\end{array}$ & $\begin{array}{l}13 \\
33\end{array}$ \\
\hline $\begin{array}{l}\text { Predicted for Union/ } \\
\text { Voted for Union } \\
\text { Predicted for Union/ } \\
\text { Voted against Union }\end{array}$ & $\begin{array}{r}14.62 \\
9.14\end{array}$ & $\begin{array}{l}20.25 \\
19.28\end{array}$ & $\begin{array}{l}65.62 \\
42.86\end{array}$ & $\begin{array}{r}16 \\
7\end{array}$ \\
\hline $\begin{array}{l}\text { Predicted against Union/ } \\
\text { Voted against Union } \\
\text { Predicted against Union/ } \\
\text { Voted for Union }\end{array}$ & $\begin{array}{l}11.57 \\
12.50\end{array}$ & $\begin{array}{l}17.14 \\
22.50\end{array}$ & $\begin{array}{l}52.38 \\
25.00\end{array}$ & 21 \\
\hline
\end{tabular}

TABLE 6

Campaton Fammintrx in Mran Percentages-Election B

\begin{tabular}{|c|c|c|c|c|c|}
\hline & $\begin{array}{c}\text { Company } \\
\text { Specific }\end{array}$ & $\begin{array}{c}\text { Company } \\
\text { General }\end{array}$ & $\begin{array}{l}\text { Union } \\
\text { Specific }\end{array}$ & $\begin{array}{l}\text { Union } \\
\text { General }\end{array}$ & $\mathbf{N}$ \\
\hline Total Unit & 5.06 & 11.02 & 5.69 & 13.36 & 64 \\
\hline $\begin{array}{l}\text { For Union } \\
\text { Against Union }\end{array}$ & $\begin{array}{l}5.07 \\
5.05\end{array}$ & $\begin{array}{l}11.55 \\
10.62\end{array}$ & $\begin{array}{l}6.07 \\
5.40\end{array}$ & $\begin{array}{l}16.00^{*} \\
11.43\end{array}$ & $\begin{array}{l}27 \\
37\end{array}$ \\
\hline $\begin{array}{l}\text { Switchers } \\
\text { Nonswitchers }\end{array}$ & $\begin{array}{r}4.29 \\
5.16\end{array}$ & $\begin{array}{r}9.14 \\
11.24\end{array}$ & $\begin{array}{l}5.14 \\
5.75\end{array}$ & $\begin{array}{r}9.00 \\
13.89\end{array}$ & $\begin{array}{r}7 \\
57\end{array}$ \\
\hline $\begin{array}{l}\text { Predicted for Union/ } \\
\text { Voted for Union } \\
\text { Predicted for Union/ } \\
\text { Voted against Union }\end{array}$ & $\begin{array}{l}5.00 \\
4.50\end{array}$ & $\begin{array}{r}11.80 \\
9.50\end{array}$ & $\begin{array}{l}6.60 \\
6.00\end{array}$ & $\begin{array}{l}17.55 \\
13.50\end{array}$ & 20 \\
\hline $\begin{array}{l}\text { Predicted against Union/ } \\
\text { Voted against Union } \\
\text { Predicted against Union/ } \\
\text { Voted for Union }\end{array}$ & $\begin{array}{l}5.12 \\
5.28\end{array}$ & $\begin{array}{l}10.76 \\
10.86\end{array}$ & $\begin{array}{l}5.33 \\
4.57\end{array}$ & $\begin{array}{l}11.18 \\
11.57\end{array}$ & 33 \\
\hline
\end{tabular}

cessfully predicted with those whose votes were not, we found no statistically significant difference. Those employees who we predicted would vote for the union, but who voted against, showed no greater familiarity with the company campaign than did those who we correctly predicted would vote for the union. Thus, where precampaign attitudes are not predictive of vote, the reason for the lack of predictability does not appear to be related to the campaign. 


\section{E. Relationship Between Unlawful Conduct and Vote}

We are particularly interested in measuring the impact of statements and actions that the Board currently regards as unfair labor practices or grounds on which to set aside the results of an election. Accordingly, we sought in our test studies to correlate employee perceptions of such statements and actions with vote. In the second wave of interviews, we ask a series of questions about what each party has said and done during the campaign and note all responses that the Board would regard as indicating that unlawful statements or actions have occurred. We also ask the respondent why he and other employees voted as they did, on the chance that some employees might report as a reason for their vote, or the vote of others, campaign statements or conduct not mentioned in response to our direct questions. Finally, we ask each employee directly whether the employer has utilized either threats or acts of reprisal, promises, or grants of benefit.

In determining whether unlawful conduct has actually taken place, we rely in part on decisions of the Labor Board or its Regional Directors and in part on our own investigation and analysis. If unfair labor practice charges or objections to the election are filed, we regard the official disposition of those charges as determinative of the legality of the conduct involved. Frequently, however, charges or objections will not be filed even though conduct has occurred that is arguably or even clearly unlawful. The losing party may be unaware of the conduct in question or its unlawfulness, and if the election was lost by a wide margin, may be uninterested in the possibility of obtaining a rerun or even a bargaining order. And the winning party is unlikely to protest the loser's election practices since the only remedy in such a case would be a cease and desist order of little practical value.

Where charges are not filed, we make our own determination as to legality after reading the campaign literature and reading or listening to the speeches each party made. ${ }^{18}$ In neither election $A$ nor election $B$ did the Board find that unlawful conduct occurred. ${ }^{19}$ In both, however, we concluded that

\footnotetext{
18 Where tape recordings of the speeches are available the parties generally provide us with them. In our post-election interviews with employer and union representatives we seek information as to all aspects of the campaign, including those of doubtful legality. Full disclosure is encouraged by our promise to protect the anonymity of all employers and unions involved. We do not attempt to resolve conflicts of testimony between employees and representatives of the parties as to what has been said or done unless we have copies of the literature or speech involved. If employees report certain conduct not initially mentioned to us by the employer or union representative, we will call the attention of the relevant party to it to see whether his failure to report it was an oversight. If he denies it, we accept that denial.

19 In $A$ the union filed charges under National Labor Relations Act \& 8(a)(1) \& (3), 29 U.S.C. \& 158(a)(1) \& (3) (1970), alleging a discriminatory discharge and discriminatory reductions in working hours, but the charge was dismissed by the Regional Director for lack of supporting evidence.
} 
employer statements, not called to the Board's attention by the union, were at least arguably unlawful. In each case, the statement, although phrased slightly differently, was essentially the same: if the union won the election, employees would lose their right to discuss problems individually with management. Thus, in A the company said, inter alia, "Once you have a union the company by law can no longer talk or deal with you on an individual basis about your terms and conditions of employment . . . . Now, whenever you have an individual problem, you can talk directly to us about it . . . If you decide that you want a union to do your talking for you, however, this won't be possible." Similarly, in B, the employer said that if the union won, employees "will absolutely lose their right to discuss wages, hours and working conditions with management. No one will be able to discuss privately with management their own personal cases regarding wages, hours and working conditions." Although Board decisions concerning assertions of this type are not wholly consistent, it is likely that the Board would find these statements violative of section 8(a)(1) of the National Labor Relations Act. ${ }^{20}$ In any event, these statements, whether unlawful or not, are sufficiently close to the line of illegality that their impact on the voters deserves careful analysis.

Tables 7 and 8 present the average number of employer unfair practices reported by employees in elections $A$ and $B$. The 46 employees interviewed in A reported a total of 33 employer unfair labor practices. There were no reports of unlawful conduct by the union. It was reported that the employer had stated that economic benefits might be cut in retaliation for union victory (one mention); that he might fire strikers (two); and that unionization might lead to loss of individual freedom to deal directly with the employer (24). The employees also mentioned that the employer discharged employees because of union activity (one); tried to find out which employees supported the union (two); and granted benefits to employees to discourage union activity (three).

The 64 employees interviewed in election B reported a total of 38 employer unfair practices (again, there were no reports of union unfair practices). Employees reported that the employer had threatened to discharge or inflict other economic injury on employees in retaliation for a union victory (four mentions) and had stated that unionization might lead to a loss of individual freedom to discuss problems with the employer (three) and would make a

20 See Saticoy Meat Packing Co., 182 NLRB 104 (1970); Block-Southland Sportswear, Inc., 170 NLRB 936 (1968); Winn-Dixie Stores, Inc., 166 NLRB 227 (1967); Graber Mfg. Co., 158 NLRB 244 (1966). But see C \& K Coal Co., 195 NLRB No. 196 (1972); Bostich Division of Textron, Inc., 176 NLRB No. 47 (1969). The theory on which such statements have been held unlawful is that they convey an implied threat of loss of the employees' right under National Labor Relations Act \& 9(a), 29 U.S.C. \$ 159(a) (1970), to present grievances directly to the employer and to have those grievances adjusted without the intervention of the bargaining representative. 
TABLE 7

Average Number of Employer Unfair Labor Practices-Election a

\begin{tabular}{lcccc}
\hline \hline & Reprisals & Benefits & Total & N \\
\hline Total Unit & .65 & .06 & .72 & 46 \\
For Union & .67 & .11 & .78 & 18 \\
Against Union & .64 & .04 & .68 & 28 \\
Swritchers against Union & .54 & .08 & .62 & 13 \\
Nonswitchers & .69 & .06 & .76 & 33 \\
Prediction Errors & .67 & .11 & .78 & 9 \\
Correct Predictions & .65 & .05 & .70 & 37 \\
Predicted for Union/ & .75 & .12 & .88 & 16 \\
$\quad$ Voted for Union & & .14 & 1.00 & 7 \\
$\begin{array}{l}\text { Predicted for Union/ } \\
\text { Voted against Union }\end{array}$ & .86 & .00 & .57 & 21 \\
$\begin{array}{l}\text { Predicted against Union/ } \\
\text { Voted against Union }\end{array}$ & .57 & .00 & .00 & 2 \\
Predicted against Union/ & .00 & & & \\
$\quad$ Voted for Union & & & & \\
\hline
\end{tabular}

TABLE 8

Average Numage of Emploter Untair Labor Practices-Election B

\begin{tabular}{|c|c|c|c|c|}
\hline & Reprisals & Benefits & Total & $\mathbf{N}$ \\
\hline Total Unit & .30 & 30 & .59 & 64 \\
\hline $\begin{array}{l}\text { For Union } \\
\text { Against Union }\end{array}$ & $\begin{array}{l}.52 \\
.14\end{array}$ & $\begin{array}{l}.63 \\
.05\end{array}$ & $\begin{array}{r}1.15 \\
.19\end{array}$ & .27 \\
\hline $\begin{array}{l}\text { Switchers } \\
\text { Nonswitchers }\end{array}$ & $\begin{array}{l}.14 \\
.32\end{array}$ & $\begin{array}{l}.14 \\
.32\end{array}$ & $\begin{array}{l}.28 \\
.64\end{array}$ & 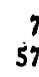 \\
\hline $\begin{array}{l}\text { Switchers against Union } \\
\text { Switchers for Union }\end{array}$ & $\begin{array}{l}.17 \\
.00\end{array}$ & $\begin{array}{l}.00 \\
.14\end{array}$ & $\begin{array}{l}.17 \\
.14\end{array}$ & i \\
\hline $\begin{array}{l}\text { Prediction Errors } \\
\text { Correct Predictions }\end{array}$ & $\begin{array}{l}.36 \\
.28\end{array}$ & $\begin{array}{l}.18 \\
.32\end{array}$ & $\begin{array}{l}.54 \\
.60\end{array}$ & $\begin{array}{l}11 \\
53\end{array}$ \\
\hline $\begin{array}{l}\text { Predicted for Union/ } \\
\text { Voted for Union } \\
\text { Predicted for Union/ } \\
\text { Voted against Union }\end{array}$ & $\begin{array}{l}.60 \\
.50\end{array}$ & $\begin{array}{l}.75 \\
. \infty\end{array}$ & $\begin{array}{r}1.35 \\
.50\end{array}$ & $\begin{array}{r}20 \\
4\end{array}$ \\
\hline $\begin{array}{l}\text { Predicted against Union/ } \\
\text { Voted against Union } \\
\text { Predicted against Union/ } \\
\text { Voted for Union }\end{array}$ & $\begin{array}{l}.09 \\
.28\end{array}$ & $\begin{array}{l}.06 \\
.28\end{array}$ & $\begin{array}{l}.15 \\
.57\end{array}$ & 33 \\
\hline
\end{tabular}

strike inevitable (three). Employees also reported that the employer had interrogated employees about their grievances (one) and about why they supported the union (one). Five employees stated that the employer treated employees barshly to discourage union activity.

In both elections, those employees who voted against union representation 
tended to report fewer unfair practices than those who voted for union representation. Switchers reported no more unfair practices than nonswitchers. Most significantly, those employees who switched from an original intention to vote for the union to an ultimate vote against the union in election $\mathbf{B}$ reported far fewer unfair practices than union voters, and in election $\mathbf{A}$ slightly fewer unfair practices than union voters.

These findings cast doubt on the Board's assumption that employees who perceive the employer as having taken or threatened reprisals against union supporters or as having granted or promised benefits to discourage union support are likely to vote against the union even though they originally favored union representation. Our data are more consistent with the hypothesis that employees are not influenced by benefits or the promise of benefits and that if they think the employer likely to take reprisals against union supporters they will conclude that the possibility of retaliation would be less if the union won the election, so they will be motivated to vote for the union.

We found almost no difference in the relative unfair labor practice perceptions of those employees whose precampaign attitudes were predictive of their voting behavior and those whose attitudes were not. Those employees who we predicted would vote for the union on the basis of their precampaign attitudes but who in fact voted against union representation reported just about the same number of unfair practices as those whose attitudes were predictive of their vote for the union. Thus our prediction errors do not appear to have been caused by employee perception of unfair practices.

There was no greater correlation between perception of actual unfair practices and vote than there was between those unfair labor practices not found by us but:perceived by employees and vote. In election $A$, there were many more reports of actual unfair labor practices than of imagined but the reports were distributed almost equally between those who voted for and against the union. In election B, the actual unfair practice was mentioned no more than the imagined and did not correlate significantly with vote. Of course, all of this is most tentative because of the relatively small numbers of employees involved and because the unfair practices were marginal in both elections.

In using reported perceptions as a measure of the effectiveness of campaign tactics, we are assuming that employees honestly report to us what they recall and that what is recalled is more likely than what is forgotten to have played a significant role in shaping voting intent. It is arguable that these assumptions are invalid. Perhaps employees affected by the campaign are unwilling to report honestly what they remember. Those coerced by the employer may be especially reticent. They may repress their recollection of threatening or coercive behavior because they do not want to recognize that their vote is attributable to fear.

While it is difficult to disprove this alternative hypothesis, there is much in 
our test studies inconsistent with it. The most sensitive questions we ask are those relating to voting and to signing a union authorization card: the answers to these questions, if known to the employer, could provide him with a basis for deciding against whom to take retaliatory action. Nonetheless, comparison of the answers given to the vote question by our sample with the total vote and comparison of the answers to the card-signing question with the union's list of card signers indicates that these questions are being answered honestly by all but a tiny proportion of the employees. It would be surprising if employees were willing to answer honestly highly sensitive questions about their own behavior while withholding information in response to questions that merely asked what the employer had said or done.

To be sure, that employees are willing to answer "sensitive" questions honestly does not necessarily mean that they will not repress perceptions of which they are ashamed, such as awareness of employer threats or promises that have dissuaded them from voting for the union. Therefore, we also ask each respondent why other employees voted against the union, on the assumption that employees unwilling to talk of their own fear of reprisal or expectation of benefits would be more willing to mention these factors as an explanation of the conduct of others. The answers to this question have not indicated a reservoir of repressed perception of unlawful conduct on the part of employees voting against union representation. Those who attribute the votes of others against the union to fear of reprisal or hope of benefits turn out to be far more likely themselves to have voted for the union than against it.

As our sample of elections studied increases, we will be able to analyze the impact of unlawful conduct across, as well as within, elections. For example, we will observe how the occurrence of unlawful conduct affects our ability to predict voting in the unit as a whole. If we can predict more accurately in legal elections, that would suggest that unfair labor practices may have an effect not discernible in individual employee responses to our questions about the campaign. If we predict that more employees will vote in favor of union representation than ultimately do so, that would suggest that the unfair labor practices discouraged employees from voting for the union; if we predict that fewer employees will vote for union representation than actually do so, that would suggest the reverse.

For some conduct currently regarded by the Board as illegal, there is an antecedent question: are employees likely to perceive intimations of employer retaliation in statements that vaguely suggest that unionization will be harmful to the employee? The Board assumes that where the employer makes statements about the results of unionization, a significant number of employees will conclude that management is threatening them with reprisals should the union win. We plan to compare elections in which the company 
makes such statements with those in which it does not. If no greater awareness of the possibility of retaliation is reported in the former than in the latter, it would suggest that employees are less attuned to the nuances of employer statements than Board doctrine would suggest. If greater awareness of the possibility of retaliation is reported, but primarily by union supporters, it may show that such tactics hurt the employer's campaign by convincing the employees that they need a union to protect them. This would be an especially persuasive inference if in such cases employees whose precampaign attitudes suggested a vote against the union ended up voting in favor of it.

\section{Some Policy Implications of the Study}

Our test results suggest some of the ways in which the study, when completed, may provide support for modifying current rules. If, as our preliminary results indicate, employees are not particularly attentive to the campaign and are not quick to catch nuances of coercion, the Board should hesitate to find unfair labor practices, and overturn elections, on the basis of ambiguous employer speeches. Should our data suggest greater familiarity with the employer's campaign than the union's campaign, one could argue that rules giving the union access to the employees during the campaign should be strengthened.

There is a good deal of confusion concerning the circumstances under which it is proper for the Board to order an employer to bargain with a union that has lost its majority status after the commission of unfair labor practices. The problem ultimately centers about the inability of either the Board or the courts to make findings as to the likelihood that the loss of majority was caused by the unfair labor practices. ${ }^{21}$ Our study can help resolve the issue by delineating the circumstances under which unfair labor practices tend to induce employees to vote against the union, and the magnitude of the effect. Bargaining orders should be limited to those cases in which the union's election defeat is by a margin within the area of possible unfair labor practice impact.

Recent judicial opinions suggest that the Board should consider such factors as employee age or skill and plant location in deciding whether to issue a bargaining order. ${ }^{22}$ Thus far our study has not shown that these or other demographic factors significantly affect employee susceptibility to unlawful conduct. Perhaps, therefore, decisions as to whether a bargaining order should be issued ought to be based solely on the unfair labor practices involved and the margin of union defeat, without regard to the demographic characteristics of the employees.

21 See Julius G. Getman \& Stephen B. Goldberg, Bargaining Orders and the Myth of NLRB Expertise, supra note 3.

22 See, e.g., NLRB v. Kostel Corp., 440 F.2d 347, 351 (7th Cir. 1971). 


\section{Effect of Test Studies on Final Research Design}

Pretesting is a necessary stage of empirical research. Our experience in studying and analyzing the test elections has greatly influenced the procedures we are utilizing in the final stage of the research. Although the original research design drew heavily on standard survey research methods, we soon realized that they are not panaceas for problems encountered in a particular study. The remainder of this paper is devoted to a discussion of some of the problems that arose in the pretests and how we have dealt with those problems in constructing our final research design.

\section{A. Choosing Elections to Study}

1. Size of the sample. Our original research design contemplated a sample of 50 elections and approximately 2000 respondents. Considerations of time and money, however, have required that this goal be reduced to a maximum of 35 elections and 1500 respondents. ${ }^{23}$ We believe, however, that a study of 35 elections, if wisely chosen, will provide us with a satisfactory sample of different campaign tactics in a variety of industries and communities.

2. Nature of the pre-election campaign. Our scheme of analysis requires us to compare voting behavior in legal and illegal campaigns. Because we choose an election for study prior to the onset of the campaign, in order to have enough examples of illegal behavior for our purposes we must be able to predict in advance when illegality is likely to occur. ${ }^{24}$ During the pretest stage we based our prediction on the answers to the following questions: (1) Does the law firm representing the employer have a reputation in the labor relations community for counseling employers who wish to campaign vigor: ously? (2) Do the representatives of the employer and the union believe that there will be a vigorous campaign? If the answers to both questions were yes we gave serious consideration to studying the election involved, our premise being that any vigorous campaign presents the likelihood, given the Board's numerous election rules, of generating illegal behavior to study.

This approach has been only partly successful. We have been able to study vigorous campaigns and those campaigns have included some unlawful behavior, but we have found no flagrant violations of the law. This has

\footnotetext{
23 The average cost of studying an election is approximately $\$ 4,000$. Major costs are data collection (salaries of interviewers, field supervisor, project coordinator, travel and lodging); data reduction (salary of a professional coder); and data processing (computer time). We have found that if we are to proceed with careful attention to relevant detail, we can study no more than two elections per month.

24 We could learn little about the impact of illegal behavior by choosing elections in which such behavior took place prior to our first wave of interviews, since in such a situation we could not engage in the "before" and "after" measurement that is the essence of the panel method.
} 
probably been due, at least in part, to our concentration on elections in which the parties are counseled by lawyers having substantial experience in NLRB elections, who are aware that blatantly illegal behavior may lead to a bargaining order. We plan to study some elections in which the parties are not represented by acknowledged experts in NLRB elections. Not only may this provide us with more instances of illegal behavior to study, but we are interested in comparing the nature and extent of unlawful conduct in campaigns involving experts and those not involving them.

3. Geographic considerations. One of the first decisions that we made was to study elections solely in the Midwest rather than to seek a nationwide sample. We did so reluctantly. It has been suggested that voters in the South, who have less familiarity with unions, are particularly susceptible to employer coercion and also are easily manipulated by a campaign based on racial issues. In order to study elections in the South, however, we would have either to train a special staff of interviewers or incur the costs involved in transporting our current stafi of interviewers hundreds or even thousands of miles for each election. Neither course is financially feasible.

It is too early to tell whether the lack of a nationwide sample will significantly affect the conclusions that can be drawn from our data. Our study embraces a diverse region ranging from such highly industrialized and urbanized areas as. Chicago and Gary to the rural parts of Kentucky, Missouri and southern Illinois and Indiana, which share many characteristics with some parts of the South. If no significant differences in patterns of response are noted among voters in these very different areas of the Midwest, it will suggest that voter behavior does not significantly vary geographically.

\section{B. Data Collection}

1. Obtaining interviews. The claims that we can make concerning the general applicability of our findings are substantially dependent on our ability to obtain interviews with a representative sample of employees. This involves two separate but related problems: first, identifying and locating employees; second, getting them to consent to be interviewed by us.

The obvious source of information as to the identity and location of employees eligible to vote in an NLRB election is the list of employee names and addresses that the employer is required to furnish to the Board for transmittal to the union. ${ }^{25}$ Initially we sought to convince the union in elections we wished to study to make the list of employee names available to is. Sometimes the union representative would request information about the study and check with higher officials before granting approval, a process

\footnotetext{
20 See Excelsior Underwear, Inc, 156 NLRB 1236 (1966); NLRB v. Wyman-Gordon
} Co., 394 U.S. 759 (1969). 
that deterred us from studying some elections because of the delay involved. Sometimes the union declined to cooperate for fear that the employer would make a campaign issue of its doing so. ${ }^{28}$

The fear expressed by union organizers that making the list available to us might become a factor in the campaign was not wholly groundless. In some of the elections we studied the employer did attack the union for its cooperation with us and in those elections a significant percentage of employees refused to be interviewed, thereby undermining the validity of our findings. Our data from such elections might not reveal the true impact of coercion because employees who were frightened refused to talk with us.

We sought to eliminate the problems inherent in obtaining names and addresses from either the employer or the union by requesting the Board to make them available to us. The Board refused, contending that our study represented an unwarranted invasion of employees' privacy, that we might upset the "laboratory conditions" under which it seeks to conduct elections and that at the very least our study would lead to the filing of unmeritorious objections that would delay the Board in processing the election.

On August 6, 1970, we filed suit against the Board in the United States District Court for the District of Columbia, asserting that we were entitled to the lists of employee names and addresses under the Freedom of Information Act. ${ }^{27}$ The district court ordered the Board to make the lists available to us and its decision was affirmed by the Court of Appeals for the District of Columbia Circuit.28 In rejecting the Board's contentions, the court of appeals concluded that there was no proof that our study would necessarily interfere with the conduct of Board elections. The court also stated:

... [O]ur finding is that disclosure for purposes of appellees' study is clearly warranted. The invasion of employee privacy strikes us as very minimal, and the possible detrimental effects of the study in terms of delaying the election process as highly speculative. ${ }^{29}$

\footnotetext{
20 Similar problems could be expected if we sought to obtain employee names and addresses from the employer. Since he has power to affect the economic well being of employees, it is crucial that the study be conducted as independently as possible of him. If it became known that the employer made available to us the list of names and addresses, some employees might doubt the independence of the study and might refuse to cooperate or not answer truthfully. The same risk exists, although in lesser degree, when the names come from the union.

27 Act of July 4, 1966, Pub. L. No. 89-487, 80 Stat. 250, amending Administrative Procedure Act, ch. 324, 3, 60 Stat. 238 (1946). Although Pub. L. No. 89-487 was repealed, its substantive provisions were enacted into the United States Code by Act of June 5, 1967, Pub. L. No. 90-23, 81 Stat. 54, 5 U.S.C. $\$ 552$ (1970).

28 Getman v. NLRB, 450 F.2d 670 (D.C. Cir. 1971). The Board requested the Supreme Court to stay the district court's order, but its request was denied by Mr. Justice Black. NLRB v. Getman, 404 U.S. 1204 (1971).

29450 F.2d at 677 .
} 
Accordingly, on August 31, 1971, nearly two years after we had requested the Board to provide us with employee names and addresses, it was ordered to do so. ${ }^{30}$

Our success in the Freedom of Information Act litigation was a major breakthrough in our efforts to maximize our response rate. We also developed other procedures designed to achieve the same goal. At the pretest stage we sent each employee a long letter describing the project, accompanied by a newspaper article reporting our National Science Foundation grant and by a two-page mimeographed document called "Some Answers to Your Questions." The latter, written in question and answer form, contained answers to the most common employee questions about the study. We assumed that by providing the employees with this volume of material we would assure them of our bona fides and increase the likelihood of obtaining an interview.

Our pretest experience, in which we discovered that the employees were reading our material with no more care than the material sent out by the parties, led to serious doubts about the value of our sending so much information to the employees. ${ }^{31}$ These doubts were strengthened by discussions with survey research experts who indicated their belief that providing a potential respondent with considerable information before the interview did no more than enable him to think of reasons for not being interviewed. ${ }^{32}$ We now send each employee a letter telling him very briefly about the study and enclosing the newspaper article reporting our NSF grants. We hope thus to pique his curiosity and make him willing to listen to the interviewer when he calls for an appointment. ${ }^{38}$ Additionally, we try to get an article about the study published in the local newspaper a few days before we schedule the interviews. Other survey researchers have found that such articles are extremely helpful in obtaining cooperation from respondents. ${ }^{84}$

80 For a general discussion of the difficulties involved in obtaining information from the government, see Joan M. Katz, The Games Bureaucrats Play: Hide and Seek Under the Freedom of Information Act, 48 Tezas L. Rev. 1261 (1970).

31 Such doubts were not lessened by the experience, common to our interviewers, of introducing oneself at the door, referring to the study, its neutrality, confidentiality, etc., then having a wife call to her husband, "Joe, the guy from the union is here!"

' 82 Conversations with Charles F. Cannel, Program Director, Survey Research Center, University of Michigan, August, 1971. The use and nature of advance letters by a number of survey research facilities is reported in 3 Survey Research, No. 7 (Survey Research Laboratory, Univ. of Illinois, Summer 1971).

33 Another change from the pretest design is that the interviewer is authorized to conduct the first wave interview over the telephone if the respondent prefers that to arranging a personal interview. We discovered that some respondents who are reluctant to have our interviewers visit their homes are perfectly willing to be interviewed by telephone. Preliminary analysis shows no significant differences in either the quantity or quality of the data obtained through telephone interviews as compared to personal interviews.

34 R. Kahn \& Charles Cannell, The Dynamics of Interviewing: Theory, Technique and Cases 66 (1961). 
We have spent a great deal of time since the pretests training our interviewers in those techniques that we and others have found to be most effective in obtaining an interview from an initially hesitant respondent. When a potential respondent is doubtful, the interviewer is instructed to appeal to his sense of altruism, ${ }^{35}$ to convince him that he can contribute to a study that will help other working people. At times the initial interviewer is unable to obtain an interview, but suspects that his failure may be due to a personality conflict with the respondent. In such situations the respondent is reassigned to another interviewer.

We have studied four elections utilizing these new procedures. The results have been most encouraging. Our overall refusal rate at the first-wave interview has been only 9.5 per cent. In one election we had not a single refusal in a sample of 34 . Our second-wave refusal rate is only three per cent.

It has become clear to us and to our interviewers that almost all employees enjoy the interview experience. We are interested in what they have to say; we want to know how they feel about their job and about unionism. For many employees our sincere interest in their ideas about this significant aspect of their life is both a novel and pleasing experience.

2. Selecting and training interviewers. The role of the interviewer in survey research is crucial. He has the ultimate responsibility for obtaining the interview and the desired information. We learned in the course of the pretests that our study imposed even greater demands than usual on the interviewer. It is rare that a survey research project involves issues as sensitive as does ours. It is equally rare in survey research to utilize as many open-ended questions as we must in order to determine, with as much precision as possible, the employee's perception of what has been said and done during the preelection campaign.

Our original staff of interviewers-housewives and undergraduate students all of whom had considerable experience in survey research interviewingproved inadequate for our purposes. To some extent they appeared to lack the persuasive skills necessary to obtain an interview, though that may have been a function of the difficulties under which the study labored before we were able to obtain employee names and addresses from the Board. It was plain to us, however, that they were unable, despite extensive training, to master the techniques of probing required by open-ended questions. For example, in analyzing our first test studies, our ability to draw meaningful conclusions was often thwarted by the interviewer's failure to probe an ambiguous response. Thus, an answer "The company said we would lose benefits if we voted for the union," is difficult to use in analysis because it does not

35 See Stephen A. Richardson, Barbara Snell Dohrenwend \& David Klein, Interviewing: Its Forms and Functions 62-63 (1965). 
specify why benefits would be taken away. The coder cannot tell whether the employee perceives the employer as threatening to take benefits away in retaliation for a union victory or as anticipating that a union victory will have a harmful effect on the operation of the business so that the employer will be financially unable to maintain the existing level of employee benefits. The interviewer must be trained to probe for further information. ${ }^{\mathbf{3 6}}$

We discovered after some experimentation that law students made ideal interviewers for this study. There are several reasons why this is so. First, law students are experts in taking down what other people say. Second, they are attuned to the legal nuances of our project and capable of understanding what we want from the respondents. Third, they are skilful at probing since the question-and-answer form of dialogue has been an integral, indeed dominant, part of their educational experience. ${ }^{87}$

3. Number of interviews. Our original research design, derived from the political election studies, provided for four interviews with each voter. We sought to identify shifts in voting intent during the campaign and to correlate them with contemporaneous campaign tactics. It became apparent in the course of the pretests that this scheme was unrealistic, primarily because the typical NLRB election campaign lasts no more than one or two weeks. There is little point to conducting the first few waves of interviews, designed to measure the impact of the campaign, prior to the commencement of the campaign. Nor would it be practical to jam three interviews into 7-14 days of campaigning in the hope of relating vote shifts to campaign tactics. Not only would employees be unlikely to consent to such frequent interviewing, but the paucity of vote switching in such a brief period of time makes the costs of the interviewing far outweigh the value of the data collected. Accordingly, we decided in the latter stages of the pretests to conduct only one pre-

${ }^{86}$ An appropriate probe in response to the statement mentioned above might be, "How do you think the loss of benefits might come about?" A probe that mentioned possibilities such as "Did he say whether the loss of benefits might come in retaliation for union victory?" would be leading and totally inappropriate. While the technique may sound simple, it is difficult to implement in an actual situation for an interviewer who does not understand clearly the objectives of the study.

37 We have recruited three separate staffs of law student interviewers, one from Indiana University to handle first wave interviews in elections in Indiana, Kentucky, southern Illinois, and the St. Louis area; one from the University of Chicago and Northwestern to handle first wave interviews in Northern Illinois and Iowa; and one from the University of Illinois to handle second wave interviews by phone. Each of these interviewers has had the benefit of considerable training both in the classroom and the field. Training sessions have been conducted on techniques for getting the interview, how to control the pace of the interview (in order to be able to record all the respondent says), when and how to probe, appropriate answers to questions that may arise during an interview and how to set up a second wave interview. Additionally, we accompanied interviewers on interviews during the pretest stage and conducted individual performance evaluations with them. 
election interview, the purpose of which would be to measure precampaign attitudes and vote intent and collect demographic data. Questions about the campaign are limited to the post-election interview, which takes place promptly after the election. ${ }^{38}$

We also gave serious consideration to omitting the preelection interview altogether in favor of a research design that would consist solely of a single post-election interview. The advantages of such a change would be manifold. Since we would not have to choose an election for study until the campaign was complete, we could be certain that we had a fair sample of both legal and illegal campaign behavior. Employee cooperation might be easier to obtain once the tensions of the campaign had dissipated. Finally, data collection costs could be reduced substantially.

We decided to retain the panel design for one compelling reason-there is no other means by which we could determine with certainty precampaign attitudes and the voting intentions of employees, both of which are crucial to our study. Were we to ask employees, after the election, what their attitudes and voting intent had been prior to the campaign, we would have little confidence in their answers. Either a faulty memory or an unwillingness to admit to having changed his mind might deter an employee from reporting prior attitudes or voting intent inconsistent with those held after the election. Accordingly, we have chosen to retain the two-interview research design, one before and one after the election campaign, as the most effective means of determining attitudes and voting intent (or vote) at each stage.

4. Interview schedules. Just as our initial four-wave design was powerfully influenced by the political election studies, so were our initial interview schedules. Our current interview schedules, now in their eighth draft, have been significantly changed as a result of our pretest experience. Some questions have been dropped or rephrased because they were ambiguous or provoked hostility. ${ }^{39}$ Other questions have been altered or added either because they did not elicit the data we needed to test existing hypotheses ${ }^{40}$ or because the pretests suggested new hypotheses that we wished to explore. ${ }^{11}$

38 The great bulk of the second wave interviews take place within 24 hours of the election and all but a very few within 72 hours.

89 One example of a question, the ambiguity of which appears obvious in hindsight, was this: "Unions hardly ever call unnecessary strikes. Do you agree or disagree?" Many respondents, quite understandably, had trouble unscrambling the negatives on that question, which we revised to read, "When a strike is called, it is generally for a good reason. Agree or disagree?".

40 We originally asked all employees who signed union authorization cards: "If you can remember, what was your reason for signing the card?" The hypothesis to be tested is that employees who sign union cards do so because they want union representation. Pretesting revealed that an employee might answer the question by saying, "Everybody else was signing." In analyzing such answers, we realized that we did not know whether an employee who gave us such an answer signed only because everyone else was doing so 


\section{Data Reduction}

In order to test our hypotheses about the effect of the campaign, we must quantify responses to our openended questions. This procedure, known as content analysis or coding, reduces verbal responses to essentials and groups similar responses into a standard set of categories that are represented numerically. ${ }^{42}$ The development of these standard categories enables us to code each employee's responses in such a way that we can compare perceptions of the campaign among various groups of employees within a particular election as well as compare campaign content across elections.

Although the development of standard coding categories for open-ended questions is always difficult, the character of our study presents particular problems. Our code must be able to cope with a wide range of possible responses at a high level of specificity. In an active campaign, the number of possible responses to a question such as "What did the employer say in his letters or other written material?" is enormous. Furthermore, since we are testing the Board's hypothesis that employees recall with specificity what has been said, categories available for employee responses must be similarly specific. At the same time the categories must not be so specific that the value of combining answers for purposes of statistical analysis is lost. Finally, the categories must not overlap, lest the decision where to place a particular answer become arbitrary.

We began with a code that we thought contained appropriate categories for most of the answers we were likely to elicit. Some categories have since been added to take account of responses we had not anticipated; others have been

or also because be wanted union representation. We now ask all card-signers: "At the time you signed the card, did you or did you not want the Union to get in at the Company?".

11 In the pretest stage, we noted a persistent relationship between the amount of reported discussion with friends about the union or the election and vote. Those employees who reported a substantial amount of discussion tended to be union supporters. This suggested the hypothesis that employees who did not support the union were those employees who were isolated from the life of the plant, and, as a result of their isolation, were not inclined to participate in the employee-based union movement. Alternatively, it is possible that those employees who were predisposed to vote against the union tended not to participate in plant discussions about the union either because their minds were made up or because there was no active group of anti-union employees with whom to discuss their anti-union sentiments. In order to determine whether the anti-union employee is isolated from plant society, we added the following question: "On the whole, would you describe the people you work with as friendly or not friendly?". Presumably, an employee who is integrated into the plant society will see his fellow workers as friendly, the isolated employee will see them as not friendly.

42 See Bernard Berelson, Content Analysis in Communications Research (1952); A Manual for Coders: Content Analysis at the Survey Research Center (Institute for Social Research, University of Michigan, 1961). 
combined because we found that neither professional coders nor we ${ }^{43}$ could satisfactorily distinguish between them in attempting to categorize the answers to our questions. For example, an early version of the code contained, as possible statements as to why the employees should favor unionization, the following two categories:

$830=$ Union Strength $:$ strength of union will balance employer strength.

$860=$ Participation in Employer Decision: Union will provide employees with voice in determining wages/hours/working conditions; important decisions will not be made by employer alone.

The categories were, we thought, analytically distinguishable, the former emphasizing the increase in employee power vis-à-vis the employer flowing from unionization, the latter emphasizing the democratic procedures that unionization could be said to entail. In the event, the distinction proved too subtle to be useful as we frequently could not decide which of these aspects of unionization the employee was referring to when he said, for example, "We would be better off with collective bargaining" or "The Union will stick up for us." Accordingly, the two categories were combined.

In comparing actual answers with the code categories into which we sought to place them it became apparent that much of the richness and variety of employee comments is lost when they are reduced to their lowest common denominator and placed in a particular code category. In interviewing employees we have been struck by how different flesh and blood workers are in their responses from the simplistic model that the Labor Board's opinions presuppose. The opinions often imply that employees are empty vials into which the content of the campaign is poured. But in the interview process one develops a definite sense that employees are evaluating the campaign statements and actions in terms of their own individual values and beliefs. We hope to be able to retain and convey some sense of the individuality of employee responses to our questions by recording and retaining the most interesting and colorful for illustrative purposes.

\footnotetext{
43 All coding to date has been done by a professional survey coder. We have limited our role to checking a random sample of answers coded by her, conferring with her on the appropriate coding of borderline or novel responses, and working with her in the development of new code categories.
} 